Journal of Clinical Investigation

Vol. 42, No. 12, 1963

\title{
THE PTEROYLGLUTAMATE COMPONENTS OF AMERICAN DIETS AS DETERMINED BY CHROMATOGRAPHIC FRACTIONATION
}

\author{
By C. E. BUTTERWORTH, JR., RAFAEL SANTINI, JR., AND \\ WALTER B. FROMMEYER, JR.
}

(From the Department of Medicine, University of Alabama Medical Center, Birmingham, Ala.)

(Submitted for publication February 12, 1963 ; accepted August 22, 1963)

Folic acid activity, as determined by conventional bacteriological assay procedures, reflects the presence of a number of compounds other than pteroylglutamic acid (PGA). For example, one popular test organism, Streptococcus fecalis, will show a growth response in folic acid free medium to at least ten derivatives of PGA in addition to thymine, hypoxanthine, theobromine, guanidine, uric acid, and several other related compounds (1). Another organism, Lactobacillus casei, shows growth with a somewhat wider range of PGA derivatives, including both methylated and triglutamate forms that do not support growth of $S$. fecalis (2). Under these circumstances, the practice of expressing the growth-supporting ability of crude dietary materials in terms of a single reference standard may not give a true indication of the PGA content of foods, because food may contain a mixture of compounds with folic acidlike activity (3). Nevertheless, most dietary tables on the folic acid content of foods are based on such assays.

The discrepancy between the amount of folic acid activity in diets and the amount of pure PGA required for the treatment of tropical sprue has led to the suggestion that humans may have a specific requirement for PGA (3). It therefore seemed important to assess the quantity of PGA available in the unsubstituted form from ordinary foods and to investigate the amount of folic acidlike activity that is present in forms other than pure PGA. A method has been employed in which factors with folic acid-like activity are chemically

* Supported by research contract DA-49-193-MD-2299 from the U. S. Army Medical Research and Development Command, Office of the Surgeon General, Washington, D. C., and grant CA 04508-04 from the National Cancer Institute, Bethesda, Md., and Clinical Research Center grant 2M01 FR-3203, National Institutes of Health, Bethesda, Md. Presented in part before the Southern Society for Clinical Investigation, January 25, 1963. Clin. Res. 1963, 11, 65 (abstract). isolated from foods or mixed diets and individually assayed with $S$. fecalis, L. casei, or Pediococcus cerezisiae.

\section{METHODS}

The procedure of the Association of Official Agricultural Chemists (4) with minor modifications was used for assay of folic acid.

\section{S. fecalis procedure}

Assay medium. "Bacto" 318-dehydrated was used. ${ }^{1}$ To rehydrate this basal medium, $75 \mathrm{~g}$ was suspended in $1 \mathrm{~L}$ of distilled water, then heated to boiling for $3 \mathrm{~min}-$ utes, and allowed to cool to room temperature.

Phosphate buffer. Prepared as described by Flynn (4).

Standard folic acid solution. Prepared as described by Flynn (4).

Test organisms. Stock cultures of S. fecalis (ATCC $8043)^{2}$ were prepared by stab inoculation of bacto-micro assay culture agar. After incubation at $37^{\circ} \mathrm{C}$ for 18 to 24 hours, the cultures were stored in a refrigerator at $4^{\circ} \mathrm{C}$. An assay inoculum was prepared by subculturing from the stock culture into a.tube containing $10 \mathrm{ml}$ of the bacto-micro inoculum broth. This inoculum was incubated at $37^{\circ} \mathrm{C}$ for 24 hours and then centrifuged under aseptic conditions; the supernatant liquid was decanted and discarded. The cells of the inoculum were resuspended in $10 \mathrm{ml}$ of freshly sterilized $0.9 \%$ saline solution. This procedure of washing and centrifuging was repeated 3 times. The washed cells were then suspended in $10 \mathrm{ml}$ of sterile saline solution. One $\mathrm{ml}$ of this suspension was aded to $9 \mathrm{ml}$ of sterile saline, and one drop of this suspension was used to inoculate the assay culture tubes.

Chicken pancreas (conjugase) preparation. Approximately $10 \mathrm{~g}$ of fresh chicken pancreas was homogenized in a Waring Blendor with approximately $35 \mathrm{ml}$ of phosphate buffer at $\mathrm{pH}$ 7.2. The homogenate was then diluted to $50 \mathrm{ml}$ with distilled water. This solution was distributed equally into ten test tubes and stored in the freezer at $-20^{\circ} \mathrm{C}$. This method is similar to the preparation procedure described by Mims and Laskowski (5). Before use, $1 \mathrm{ml}$ of this solution was diluted to $10 \mathrm{ml}$ with distilled water.

"Free" folic acid activity. Crude diets were homogenized in a 1-gallon blender. Water was added to facili-

1 Difco Laboratories, Detroit, Mich.

2 American Type Culture Collection, Washington, D. C. 
tate homogenization. Final total diet weights were recorded to permit calculation of results, and samples of approximately $250 \mathrm{~g}$ were stored in the freezer at $-20^{\circ}$ $C$ until ready for use.

Duplicate assays for "free" folic acid activity were carried out as follows: A 5-g portion of the homogenate was placed in a small blender and homogenized for an additional 3 minutes with $35 \mathrm{ml}$ of distilled water and 40 $\mathrm{ml}$ of phosphate buffer at $\mathrm{pH}$ 7.2. The homogenate was then transferred to an Erlenmeyer flask, along with 100 $\mathrm{ml}$ of distilled water to rinse the blender, autoclaved for 15 minutes at 15 pounds pressure, and allowed to cool to room temperature. Each sample was then diluted to $200 \mathrm{ml}$ with distilled water and filtered through a Seitz filter pad. Samples of the filtrate were taken in duplicate, diluted if necessary to $5 \mathrm{ml}$ with distilled water, added to $5 \mathrm{ml}$ of assay media, autoclaved at 7 pounds for 15 minutes, cooled, and inoculated with one drop of the $S$. fecalis suspension. After incubation for 18 hours at $37^{\circ} \mathrm{C}$, turbidity was determined in a spectrophotometer ${ }^{3}$ at $650 \mathrm{~m} \mu$ and compared with a standard PGA growth curve determined simultaneously.

"Total" folic acid activity. Diet samples were prepared as described above for free folic acid activity, except that after the initial autoclaving, they were cooled to room temperautre and allowed to incubate at $37^{\circ} \mathrm{C}$ overnight with $5 \mathrm{ml}$ of the diluted chicken conjugase preparation. After incubation, the samples were autoclaved for 5 minutes at 15 pounds pressure to inactivate the conjugase. The samples were then cooled, diluted to $200 \mathrm{ml}$ with distilled water, and filtered through Seitz filter pads. After proper dilution of the filtrate, $5-\mathrm{ml}$ samples were assayed with $5 \mathrm{ml}$ of the assay media as described in the preceding paragraph. Blank determinations were accomplished by the same procedure on the conjugase preparation without added dietary material.

\section{L. casei procedure}

Preservative mixture, maintenance media, L. casei stock culture (ATCC 7469), folic acid standard, folic acid standard curve, and the glassware were all prepared as described by Herbert (6).

Assay medium. Folic acid assay medium as described by Baker and co-workers (7) was employed.4 To rehydrate this medium $94 \mathrm{~g}$ of the dry material was suspended in $1 \mathrm{~L}$ deionized water. $0.1 \mathrm{ml}$ Tween 80 and 0.5 $\mathrm{ml}$ of the preservative mixture were added. This solution was then stored in a brown polyethylene bottle in the refrigerator.

Ascorbate buffer. $23.46 \mathrm{~g} \mathrm{NaH_{2 }} \mathrm{PO}_{4} \cdot \mathrm{H}_{2} \mathrm{O}$ and $4.16 \mathrm{~g}$ of $\mathrm{Na}_{2} \mathrm{HPO}_{4} \cdot 12 \mathrm{H}_{2} \mathrm{O}$ were diluted to $1 \mathrm{~L}$ with deionized water. The $\mathrm{pH}$ was adjusted to 6.1 , and $0.5 \mathrm{ml}$ of the preservative mixture was added. Immediately before use, 1.0 $\mathrm{g}$ of ascorbic acid was added to each $100 \mathrm{ml}$ of buffer.

Free folic acid activity. The same procedure as outlined with $S$. fecalis was employed, except for the use of L. casei medium and inoculum.

\footnotetext{
3 Coleman, Junior.

4 Baltimore Biological Laboratory, Baltimore, Md.
}

Total folic acid activity. The same procedure as outlined with $S$. fecalis was employed, except for the use of $L$. casei medium and inoculum.

Citrovorum factor activity (CF). In testing for the presence of citrovorum factor (CF, 5-formyl-5,6,7,8tetrahydropteroyl-L-glutamic acid), the organism employed was $P$. cercvisiae (ATCC 8081) under conditions similar to those described for $S$. fecalis, except that synthetic $\mathrm{CF}$ was used as a reference standard as well as to maintain growth of the organism.

Charcoal adsorption. After conjugase digestion and Seitz filtration, the material in the filtrate was extracted at $\mathrm{pH} 7.0$ with $400 \mathrm{mg}$ of acid-washed charcoal (Norit A, Pfanstiehl) as in the original procedure described for isolation of the Norit eluate factor (8). The adsorbed samples were then centrifuged, and the supernatant fluid was decanted into 500-ml Erlenmeyer flasks. Duplicate samples of the supernatant fluid were taken, and the amount of folic acid-like substances not adsorbed on the charcoal was determined by the procedure for total folic acid activity. The charcoal was then washed with $60 \%$ ethanol. Three fractional elutions of the folic acid-like substances from the charcoal were then carried out with $15 \mathrm{ml}$ of ammoniacal $70 \%$ ethanol for each elution. The three eluates were then combined and lyophilized.

Adsorption isotherms at $25^{\circ} \mathrm{C}$ were determined for folic acid active material in three dietary homogenates by multiple extractions with charcoal.

Synthesis of $N^{10}$-formyl-PGA. This compound was prepared by incubating $10 \mathrm{mg}$ of PGA with $1 \mathrm{ml}$ of formic acid at $75^{\circ} \mathrm{C}$ for 30 minutes according to the method of Silverman, Law, and Kaufman (9).

$D E A E$ preparation and chromatography. The techniques of DEAE (diethylaminoethyl cellulose anion exchanger) preparation and column chromatography were based on those of Toennies and Phillips (10) and Oliverio (11). A suspension containing $100 \mathrm{~g}$ of DEAE and $1 \mathrm{~L}$ each of $0.5 \mathrm{M}$ sodium chloride and $0.5 \mathrm{M}$ sodium hydroxide was prepared. This suspension was filtered with suction through filter paper on a sintered glass funnel. The cake was transferred to a beaker, resuspended in $1 \mathrm{~L}$ distilled water, and refiltered as above. The process was repeated until the wash water reached a $\mathrm{pH}$ of 7.0. During the washing procedure, the residual suspension of fine particles was decanted and discarded toward the end of each filtration step. After the water wash, the material was suspended in $1,500 \mathrm{ml}$ of $95 \%$ ethanol, filtered, and washed finally with $1,500 \mathrm{ml}$ of absolute ethanol. The DEAE was then spread out loosely on a glass dish and allowed to dry overnight at room temperature.

Columns were prepared by pouring a distilled vater slurry of DEAE into $1-\times 30-\mathrm{cm}$ chromatographic columns equipped with a sintered glass support at the base. The column was packed with air pressure and refilled until a packed column $1 \times 25 \mathrm{~cm}$ was achieved, leaving about $2 \mathrm{ml}$ of distilled water above the column. Columns may be prepared, stoppered, and stored in a refrigerator, or used at once. Fresh DEAE was used for each fractionation and discarded after use. 
The lyophilized eluate sample or reference material was placed directly on the top of the column in an amount ranging from 75 to $150 \mu \mathrm{g}$ dissolved in approximately $5 \mathrm{ml}$ of phosphate buffer at $\mathrm{pH}$ 7.2. The appropriate quantity of the eluate was calculated on the basis of bacteriological assays of the Norit-eluates after lyophilization. The material was forced slowly through the prepared column with the aid of air pressure, with care to avoid passage of air into the DEAE. The column was washed similarly with at least $60 \mathrm{ml}$ of water distilled 3 times.

Elution of the material from the column was accomplished by a concentration gradient system at $\mathrm{pH} 7.2$ containing ascorbic acid as an antioxidant. The elution solutions were prepared immediately before use. The upper flask contained $29.25 \mathrm{~g}$ sodium chloride, $4.112 \mathrm{~g}$ ascorbic acid, and $5.72 \mathrm{ml}$ of $4.06 \mathrm{M}$ potassium hydroxide brought to a volume of $500 \mathrm{ml}$ with $0.5 \mathrm{M}$ phosphate buffer. The lower, or mixing flask, contained $4.112 \mathrm{~g}$ of ascorbic acid and $5.72 \mathrm{ml}$ of $4.06 \mathrm{M}$ potassium hydroxide brought to a total volume of $500 \mathrm{ml}$ with $0.5 \mathrm{M}$ phosphate buffer.

Fractions of $3 \mathrm{ml}$ each were collected with a volumetric fraction collector. Tubes were shielded from light during and after collection. A gravity flow rate of approximately $0.1 \mathrm{ml}$ per minute was used. One $\mathrm{ml}$ of each fraction was tested for ability to support growth of $S$. fecalis, $L$. casei, or $P$. cerevisiae as outlined above. The amount of PGA activity present in each fraction was calculated by comparison with a standard growth curve prepared concomitantly with pure PGA. In this way it was also possible to calculate the amount of activity present in the various chromatographic peaks. Curves were drawn by plotting percentile transmission (turbidity) on the ordinate and tube numbers on the abscissa of arithmetical graph paper. Assays were performed on eluates obtained in the same manner from DEAE columns without prior application of folate.

\section{RESULTS}

The free and total folic acid activity values for 17 American diets as determined by $S$. fecalis assay are shown in Table I. These values compare favorably with those reported for six Puerto Rican diets that were found to contain a daily average of $65 \mu \mathrm{g}$ of free and $140 \mu \mathrm{g}$ of total folic acid activity (12). No growth-supporting activity was found in the control determinations on the conjugase preparation so that no correction factor was necessary. Representative menus of the American diets are indicated below and in the legends of Figures 1 and 2. Table II shows the free and total folic acid activity in four diets as determined by $L$. case $i$ assay.

Adsorption experiments. The adsorption isotherms in a typical experiment are shown in Ta-
TABLE I

Folic acid activity in seventeen American diets as determined by Streptococcus fecalis assay

\begin{tabular}{cc}
\hline $\begin{array}{c}\text { Free } \\
\text { (Not conjugase treated) }\end{array}$ & $\begin{array}{c}\text { Total } \\
\text { (Conjugase treated) }\end{array}$ \\
\hline \multicolumn{2}{c}{$\mu g / 24$ hours } \\
40 & 260 \\
73 & 200 \\
63 & 260 \\
35 & 105 \\
58 & 190 \\
58 & 189 \\
50 & 100 \\
53 & 138 \\
55 & 220 \\
25 & 80 \\
33 & 108 \\
70 & 185 \\
78 & 265 \\
78 & 210 \\
50 & 120 \\
24 & 308 \\
41 & 188 \\
SD $52 \pm 14$ & $184 \pm 67$ \\
\hline
\end{tabular}

ble III. These are similar to those described by Frieden, Mitchell, and Williams (13). They indicate a recovery in three successive elutions of approximately one-half the original $S$. fecalis activity and approximately one-third the original L. casei activity. This was the number of elution steps utilized in the preparation of material for column chromatography described below. Further extraction steps increased the yield slightly, but did not alter the chromatographic pattern for $S$. fecalis, indicating no appreciable differences in the affinity of the major components for the adsorbing surface. The relatively greater loss of material having activity for $L$. case $i$ is presumed to be due to loss of nonfolates whose presence contributes to the over-all growth of the organism. The results of work that will be presented elsewhere indicate that this is not due to loss or re-

TABLE II

Folic acid activity in four American diets as determined by Lactobacillus casei assay

\begin{tabular}{cc}
\hline \hline $\begin{array}{c}\text { Free } \\
\text { (Not conjugase } \\
\text { treated) }\end{array}$ & $\begin{array}{c}\text { Total } \\
\text { (Conjugase } \\
\text { treated) }\end{array}$ \\
\hline & $\mu g / 24$ hours \\
297 & 698 \\
243 & 580 \\
37 & 1097 \\
49 & 379 \\
\hline
\end{tabular}




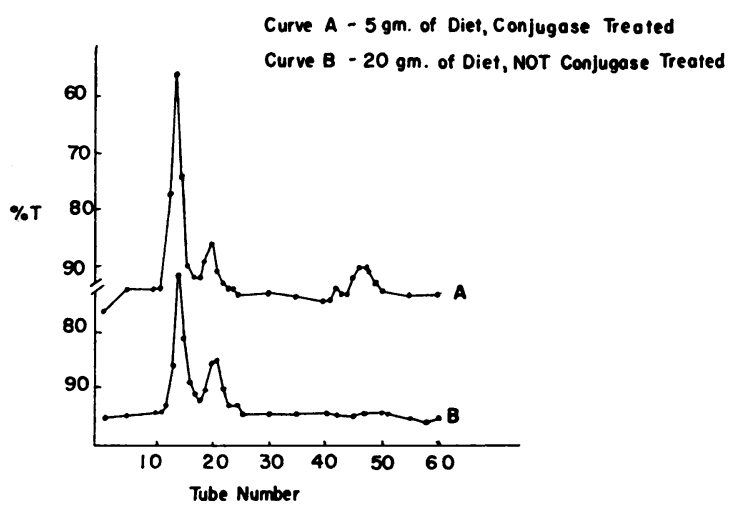

Fig. 1. PATtern OF GROWTH SUPPORT FOR Streptococcus fecalis of FRACTIONS OBTAINED FROM ONE DIET. Diet consisted of cream of chicken soup, hamburger, onions, gravy, potatoes, squash, asparagus, tomato and lettuce salad, coconut pie, bread, and homogenized milk. The upper curve represents $5 \mathrm{~g}$ of dietary homogenate that was incubated overnight with chicken pancreas conjugase. The lower curve represents $20 \mathrm{~g}$ of the same diet fractionated without prior conjugase treatment. Although the lower curve represents 4 times as much dietary material, there is no evidence of a peak between tubes 40 and 50 , which is the zone of elution for reference pteroylglutamic acid.

tention of polyglutamates, since yeast polyglutamates are recovered under the conditions described.

Figure 1 illustrates the growth-supporting activity for $S$. fecalis of DEAE fractions derived from a diet with and without conjugase treatment. Most of the growth-supporting activity was observed in two chromatographic peaks, centered at tubes 14 and 21 , respectively. The activity increased in each of these after conjugase digestion. It was also seen that conjugase digestion was associated with the development of a third peak of growth-supporting activity between tubes 45 and

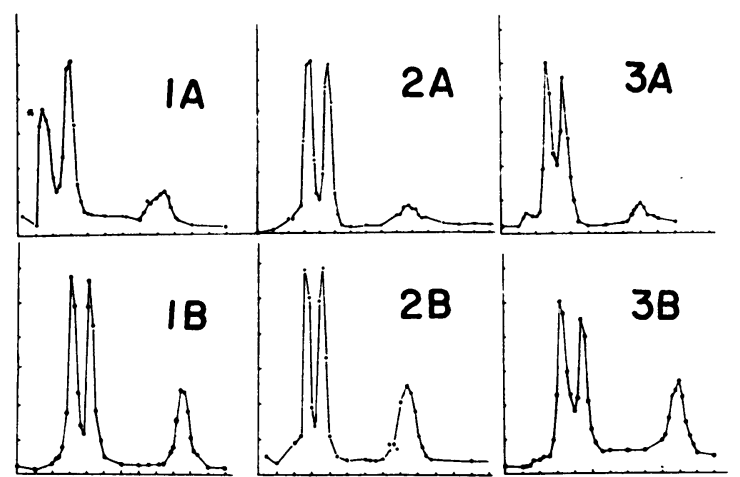

Fig. 2. PATtern OF GROWTH SUPPORT FOR $S$. fecalis of FRACTIONS OBTAINED FROM THREE LUNCHEONS (LPPER CHROMATOGRaM, A) AND RESUlts ObTained With the SAME DIET CONTAINING ADDED PTEROYLGLUTAMIC ACID (PGA) AND PROCESSED IN THE SAME WAY, SHOWING ACCENTUATION OF ONLY THE THIRD PEAK (LOWER FIGLRE, B). Menus were: $1 \mathrm{~A}(1,305 \mathrm{~g})$-cream of celery soup, beef stew, broccoli, scalloped potatoes, tossed green salad, corn bread, mocha chiffon pie, and homogenized milk; $2 \mathrm{~A}$ $(795 \mathrm{~g})$-cream of pea soup, ham loaf, potato "boats" with cheese and mustard, cabbage, tomato and lettuce salad, mayonnaise, peaches, tea with lemon and sugar, and bread and butter; 3A (1,041 g)-cream of pea soup, ham loaf, potato with cheese and mustard, black-eyed peas with snaps, ambrosia salad, butterscotch pudding, white bread, and coffee. The first peak in 1A appears blunted owing to a temporary unequal collection of fractions, but the quantity is the same as in the first peak of $1 \mathrm{~B}$.

50. A similar chromatographic pattern consisting of three peaks was observed regularly in 14 diets after conjugase treatment.

Identification of peaks. The occurrence of a new peak after conjugase digestion suggested that this component might be PGA that had been released from the naturally occurring polyglutamate form. Investigation of this possibility by filter

TABLE III

The extraction of folic acid with carbon

\begin{tabular}{|c|c|c|c|c|c|c|c|c|c|}
\hline & \multirow{2}{*}{$\begin{array}{l}\text { Amount of } \\
\text { total folic } \\
\text { acid present be- } \\
\text { fore extraction }\end{array}$} & \multicolumn{4}{|c|}{$\begin{array}{l}\text { Cumulative } \\
\text { amount of folic acid extracted }\end{array}$} & \multicolumn{4}{|c|}{$\begin{array}{l}\text { Cumulative } \\
\text { percentage of total folic acid extracted }\end{array}$} \\
\hline & & 1 & 2 & 3 & 4 & 1 & 2 & 3 & 4 \\
\hline S. fecalis assay & $\mu g / g$ & \multicolumn{4}{|c|}{$\mu g$} & \multicolumn{4}{|c|}{$\%$} \\
\hline $\begin{array}{l}\text { Lunch 18-1 } \\
\text { Lunch } 18-2\end{array}$ & $\begin{array}{l}0.32 \\
0.32\end{array}$ & $\begin{array}{l}.04 \\
.06\end{array}$ & $\begin{array}{l}.11 \\
.14\end{array}$ & $\begin{array}{l}.18 \\
.20\end{array}$ & $\begin{array}{l}.26 \\
.29\end{array}$ & $\begin{array}{l}12 \\
18\end{array}$ & $\begin{array}{l}33 \\
44\end{array}$ & $\begin{array}{l}54 \\
63\end{array}$ & $\begin{array}{l}78 \\
89\end{array}$ \\
\hline \multicolumn{10}{|l|}{ L. casei assay } \\
\hline $\begin{array}{l}\text { Lunch } 18-1 \\
\text { Lunch } 18-2\end{array}$ & $\begin{array}{l}0.84 \\
0.89\end{array}$ & $\begin{array}{l}.07 \\
.08\end{array}$ & $\begin{array}{l}.15 \\
.11\end{array}$ & $\begin{array}{l}.38 \\
.24\end{array}$ & $\begin{array}{l}.48 \\
.47\end{array}$ & $\begin{array}{l}8 \\
9\end{array}$ & $\begin{array}{l}18 \\
12\end{array}$ & $\begin{array}{l}44 \\
27\end{array}$ & $\begin{array}{l}56 \\
43\end{array}$ \\
\hline
\end{tabular}




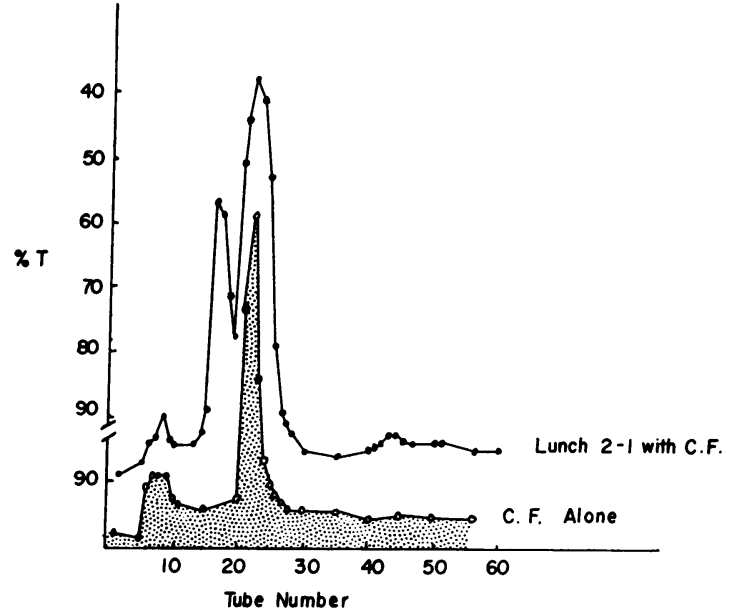

Fig. 3. Pattern of growth for $S$. fecalis of a Diet SAMPLE CONTAINING $0.030 \mu \mathrm{G}$ OF ADded CF (CALCIUM LEUCOVORIN) (UPPER CURVE) AND THE PATTERN OF GROWTH SUPPORT FOR THE SAME ORGANISM WITH THE SAME REFERENCE MATERIAL (CF) ALONE (LOWER, SHADED CURVE). Comparison of the upper curve in this figure with the curve of the same dietary material chromatographed alone (Figure 2, curve 2A) indicates that the addition of $\mathrm{CF}$ augmented only the second peak.

paper chromatography and plate bioassay as described by Nichol, Zakrzewski, and Welch (14) indicated that the material in the third peak has the same $\mathrm{Rf}$ value as reference PGA. Additional evidence that the third peak is PGA was the demonstration of a single peak between tubes 40 and 50 when a reference solution of PGA was passed through the DEAE column. There was $95 \%$ recovery of the reference material in this peak.

Figure 2 represents a series of experiments that were performed to determine the relationship of the third peak to PGA. The upper curves in each pair represent $0.12 \mu \mathrm{g}$ of folic acid activity determined by prior assay. The lower curves in each pair represent the same amount of folic acid activity plus additional synthetic PGA added to each diet sample in amounts of $0.025,0.030$, and $0.025 \mu \mathrm{g}$, respectively. Recoveries ranged from 83 to $101 \%$, with an average of $95 \%$. Although the position of the peaks varied somewhat according to flow rates, their relative pattern remained the same, and the added PGA produced augmentation of only the third peak. These results suggest that the third peak in the DEAE $S$. fecalis curves is, or contains, PGA in the monoglutamate form.
Because of the rather wide distribution of $\mathrm{CF}$ in nature, attention was directed next at the iclentification of this material in dietary extracts. Figure 3 illustrates in the shaded area the pattern of growth support for $S$. fecalis of fractions collected from a DEAE column run of $0.030 \mu \mathrm{g}$ of reference CF. ${ }^{5}$ Support of bacterial growth was observed in only one narrow zone between tubes 20 to $25 .^{6}$ The upper curve in this figure is the pattern of growth support for $S$. fecalis of fractions prepared from a diet containing $0.027 \mu \mathrm{g}$ of added reference $\mathrm{CF}$. The pattern of the plain diet is shown in Figure 2, curve 2A. Only the second peak is augmented.

Further evidence that the second peak is $\mathrm{CF}$ is presented in Figure 4 in which the same fractions forming the second peak from diets tested with $S$. fecalis also support growth of $P$. cerevisiae. This diet consisted of one pork chop, French fried

$5 \mathrm{CF}$, Calcium Leucovorin, kindly provided by Dr. T. H. Jukes, Lederle Laboratories, Princeton, N. J.

${ }^{6}$ A small zone of yellow pigment was observed between tubes 5 and 10 in eluates from columns run in blank, that is, without application of folate or dietary material. These tubes are moderately active in support of $L$. casci, but not so active in support of $S$. fccalis. They have not been included in the calculations of dietary folate.

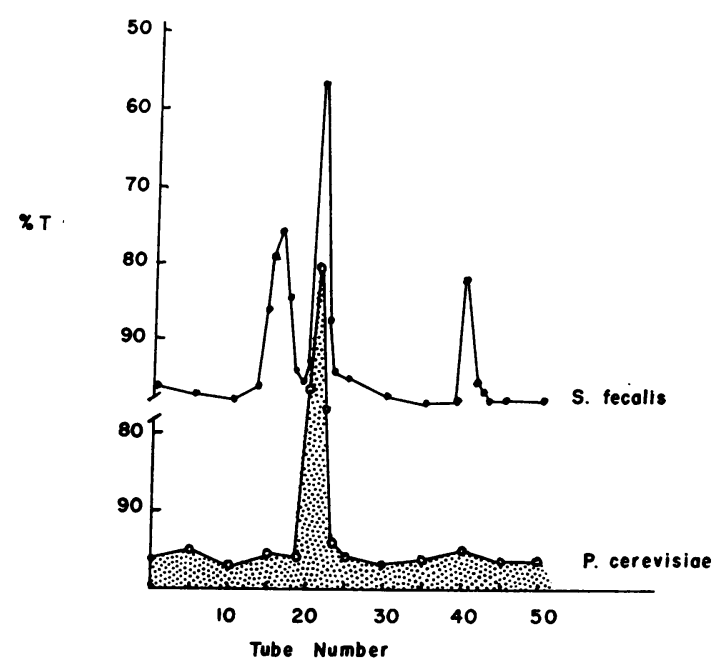

Fig. 4. PAtTern OF GROWTH SUPPORT For $S$. fecalis of A SERIES OF FRACTIONS OBTAINED By DEAE FRACTIONATION (UPPER CURVE) AND THE SAME DIETARY FRACTIONS TESTED FOR ABILITY TO SUPPORT GROWTH OF Pcdiococcus cercvisiac, INDICATING THAT THE SECOND CHROMATOGRAPHIC COMPONENT IS CITROVORUM FACTOR (5-FORMYL5,6,7,8-TETRA H YDROPTEROYL-L-GLUTAMIC ACID) (LOWER, SHADED CURVE). 

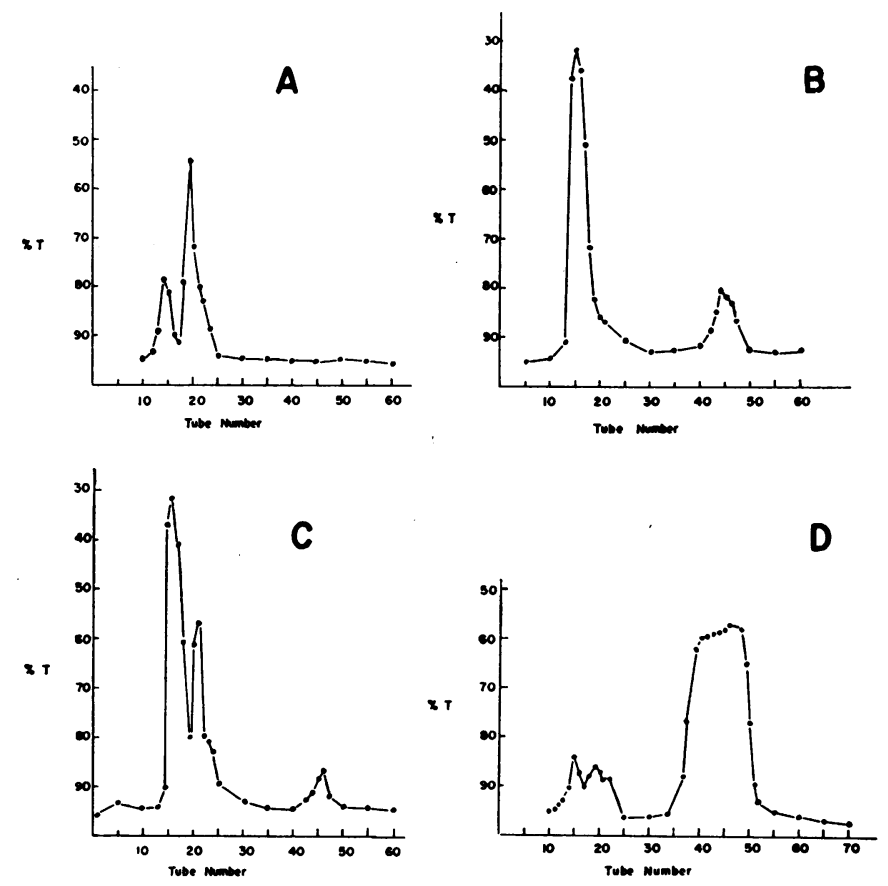

Fig. 5. A series of experiments CONCERning the nature of THE FIRST PEAK UTILIZING DEAE FRACTIONATION AND $S$. fecalis AS the test organism. See text for details. $A$ ) Chromatogram of dietary material alone; $B$ ) chromatogram of synthetic $N^{10}$ formyl-PGA, showing a small amount of residual PGA; C) chromatogram of a mixture of the materials used in $\mathrm{A}$ and $\mathrm{B} ; D$ ) the pattern obtained when the mixture of $A$ and $B$ was treated with dilute alkali to bring about deformylation. The first two components are largely converted to a product with the elution characteristics of PGA.

potatoes, turnip greens, tomato and lettuce salad, mayonnaise, canned peaches, corn bread, butter, and homogenized milk. Calculations indicate that the diets assayed in this study yield a daily average of $63 \mu \mathrm{g}$ of folic acid activity in the form of CF.

Figure 5 depicts a group of experiments concerning the nature of the first peak. A sample of $N^{10}$-formyl-PGA was synthesized according to the method of Silverman, Law, and Kaufman (9). Chromatography of the product (upper right) revealed a peak centered between tubes 15 and 20 . Approximately $90 \%$ of the original activity was converted to this compound, although a small residual peak may be seen in the PGA elution zone centered at tube number 45 . When this synthetic product was added to a luncheon (upper left) and passed through DEAE, the resultant chromatogram (lower left) represented a sum- mation of the two individual chromatograms. Thus, the first peak of the luncheon is augmented by $N^{10}$-formyl-PGA, the second peak (CF) remains unchanged, and the residual PGA that was not present in the diet sample presents itself at tube number 45 , as in other experiments. Evidence in confirmation of these findings was obtained by treating a dietary extract with $0.5 \mathrm{~N}$ sodium hydroxide at $37^{\circ} \mathrm{C}$ for 17 hours, a method described by Usdin (15) for the deformylation of formyl folates. This procedure virtually abolished the first and second peaks in dietary extracts both with and without added synthetic $N^{10}$-formylPGA (Figure 5, lower right), converting them to material having the elution characteristics of PGA.

Chromatograms that are not shown were prepared of PGA, CF, and $N^{10}$-formyl-PGA, singly and in various combinations. The results were in 


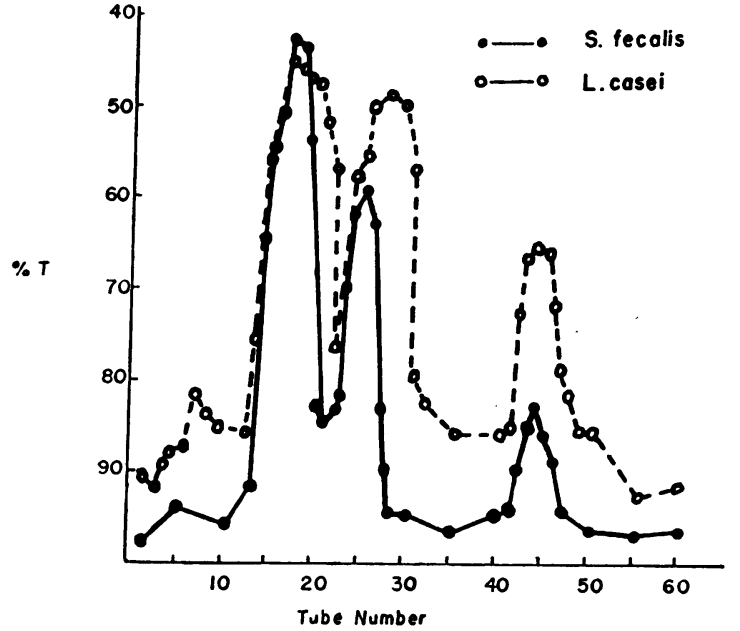

Fig. 6. Chromatographic curves of identical DEAE FRACTIONS TESTED FOR ABILITY TO SUPPORT EITHER $S$. fecalis or Lactobacillus casei. Note that the peak centered at tube 45 , which is the PGA elution zone, supports growth of both organisms. This extract was made from a special diet that was known to contain a third peak: chicken livers, mashed potatoes, broccoli, cherry salad, butterscotch pudding, corn bread, butter, coffee, and sugar. See text for further comments.

accord with the conclusions that the first peak is $N^{10}$-formyl-PGA, the second is $\mathrm{CF}$, and the third is PGA.

Comparison of S. fecalis and L. casci. The chromatographic growth-support pattern of dietary extracts is depicted in Figures 6 and 7 in which identical fractions have been tested with both $L$. casei and $S$. fecalis. Growth curves are similar, although in some cases factors having activity for $L$. casei continue to leave the column after the second $S$. fecalis peak has reached base line. It is believed that this represents elution of other compounds, such as methylfolates, which are active for $L$. case $i$ but not for S. fecalis.

Tables I and II indicate that $L$. casei shows several times more folic acid activity in diets than $S$. fecalis. Parallel charcoal extractions (Table III), however, indicate a relatively greater loss of material having activity for $L$. case $i$ than for S. fecalis. This difference in affinity for charcoal suggests that some of the factors supporting L. case $i$ are not PGA derivatives. In general, $L$. case $i$ seems more sensitive and yields higher rates of growth at lower concentrations of nutrient than $S$. fecalis. In our experience, how- ever, there is more variability in the growth response with $L$. casei. The latter phenomenon may be attributed to the fact that this organism is less fastidious in its growth requirements and responds to a wider range of compounds whose presence or interaction leads to varying rates of growth.

The distribution of folic acid-like activity among the three peaks has been calculated on a percentage basis for ten diets with $S$. fecalis as the test organism and on two diets with $L$. casei as the test organism. Results are shown in Table IV. With these ratios applied to a mean daily intake of $184 \mu \mathrm{g}$ of folic acid activity, the three peaks yield 101,63 , and $20 \mu \mathrm{g}$, respectively, of folic acid activity for $S$. fecalis in terms of a PGA standard. Assays of folic acid activity in the ten separate diet samples before and after passage through DEAE columns indicate a recovery of $95 \%(\mathrm{n}=10$, range $=72$ to $109 \%$, mean $=95$, $\mathrm{SD}= \pm 5 \%)$

The diet yielding the lowest total of folic acid activity, i.e., $80 \mu \mathrm{g}$, consisted of : breakfast-toast and coffee; lunch-bologna sandwich on white

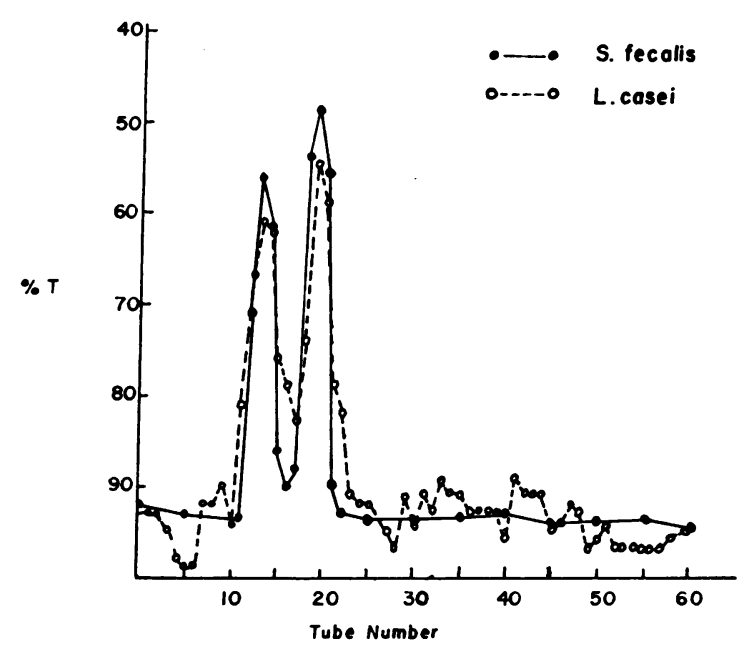

Fig. 7. Chromatographic curves of identical DEAE FRACTIONS TESTED FOR ABILITY TO SUPPORT EITHER $S$. fecalis oR L. casei. This extract was made from a diet that had been specially selected to include foods having virtually all of their activity for $S$. fecalis in the form of the first two components. There is no appreciable growth support for either organism in the PGA elution zone between tubes 40 and 50 . The diet consisted of cream of chicken soup, baked stuffed green peppers, mashed potatoes, baby lima beans, rolls and butter, purple plums, and iced tea. See text for further comments. 
TABLE IV

Folic acid-like components in dietary extracts after DEAE chromatography

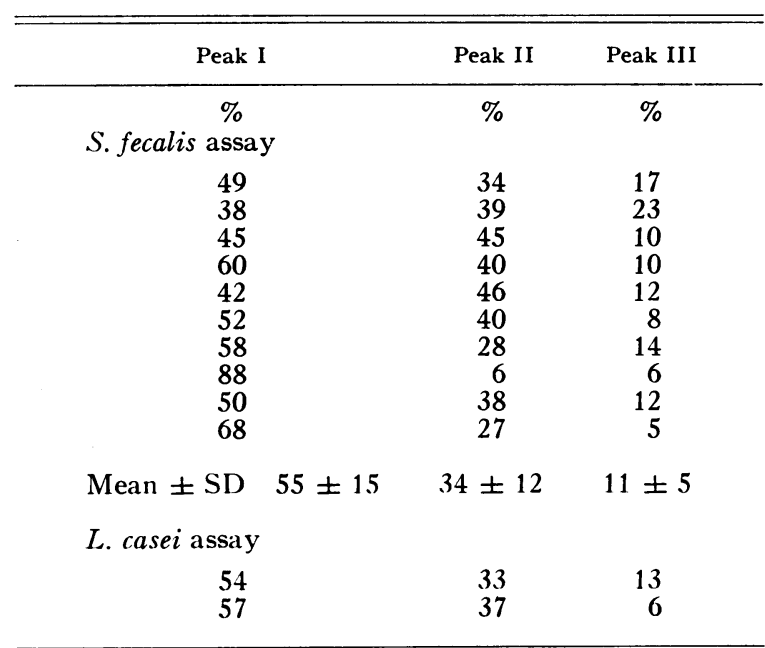

bread with lettuce and mayonnaise, $\frac{1}{2}$ pint skimmed milk, 1 fresh pear, and 5 vanilla wafers; and supper-two baked pork chops, mashed sweet potatoes, marshmallows, creamed field peas, 1 slice whole-wheat bread, and $\frac{1}{2}$ pint homogenized milk.

This diet would provide $4 \mu \mathrm{g}$ of folic acid activity daily as available PGA on the basis of evidence that the third peak is PGA, amounting in this instance to $5 \%$ of the total.

\section{DISCUSSION}

The need for some form of folic acid in human nutrition has been amply demonstrated by many investigators since 1945 , but the minimal daily requirement has not yet been accurately established. Oral doses of 5 to $15 \mathrm{mg}$ daily have been recommended in the past for the treatment of certain so-called folic acid deficiency diseases (16). A reappraisal of man's daily folic acid requirement, however, became necessary recently when Sheehy and associates (17) demonstrated the effectiveness of small oral doses of folic acid in the treatment of tropical sprue. There is evidence that these patients develop and maintain megaloblastic anemia even while consuming a diet that contains an average of $140 \mu \mathrm{g}$ of folic acid activity daily according to bacteriological assay (12). The addition of $25 \mu \mathrm{g}$ of pure synthetic PGA to the daily oral intake of certain patients resulted in the correction of the clinical manifes- tations of the disease. It is paradoxical that such patients should respond to a dose of folic acid that is smaller than the amount measured bacteriologically in the diet. This observation emphasizes at least one of the limitations of the bacteriological method for assay of crude diets. This observation has also led to the suggestion that man may have a specific requirement for PGA and may be unable to utilize certain dietary folates under some circumstances (3).

It seems unlikely that the beneficial result of the oral administration of $25 \mu \mathrm{g}$ of folic acid was merely an additive effect. Several subsequent observations have indicated that the daily requirement for $\mathrm{PGA}$ may be less than the total folic acid-like activity in crude diets as juclged by bacteriological assay. Zalusky and Herbert (18) demonstrated a beneficial response in the megaloblastic anemia of scurvy when $50 \mu \mathrm{g}$ of PGA was added to a diet devoid of folic acid. Evidence has also been presented through studies of experimental folic acid deficiency in humans (19, 20) that the minimal daily PGA requirement is about $50 \mu \mathrm{g}$.

Velez, Ghitis, Pradilla, and Vitale (21) have recently reported the effectiveness of $5-\mu \mathrm{g}$ oral closes of PGA in the treatment of the megaloblastic anemia of infancy associated with kwashiorkor. This corresponds to a dose of approximately $1 \mu \mathrm{g}$ per $\mathrm{kg}$ of body weight and was given along with a diet that was estimated to contain less than $10 \mu \mathrm{g}$ of folic acid activity per day. Hansen and Weinfeld (22) have reported that 2 $\mu \mathrm{g}$ per $\mathrm{kg}$ of PGA will give a diagnostic reticulocyte response in man within 10 to 12 days in all cases of megaloblastic anemia in which folic acid deficiency is the only limiting factor for normal erythropoiesis.

Girdwood (23) has observed that it would be difficult to devise a diet to produce folic acid deficiency, since this material is present in both meats and vegetables. Herbert (24), however, has devised a palatable diet that has been rendered folate deficient by prolonged cooking in large volumes of water.

The present study demonstrates that ordinary American diets contain an average of $52 \mu \mathrm{g}$ of free folic acid-like activity per day and an average of $184 \mu \mathrm{g}$ of total folic acid-like activity per day after conjugase digestion as determined by $S$. 
fecalis assay. Chromatographic fractionation has shown that the bacteriologically active material present before digestion (free) is in the form of two factors, neither of which is PGA. Similar fractionation after digestion with chicken pancreas conjugase yields a third component that in two chromatographic systems corresponds to a synthetic reference standard of PGA (Figure 1). This fraction constituted $11 \%$ of the total.

It is not possible to exclude the possibility that folyl- $\gamma$-glutamate might have similar elution properties under the described experimental conditions. This seems unlikely, however, since both Usdin (15) and Noronha and Silverman (25) have shown that each additional glutamic acid moiety causes a successive increase in affinity for the column and a corresponding delay in the elution sequence. Thus, pteroylmono-, di-, and triglutamates are eluted in that order from both DEAE and TEAE. The present system yields adequate separation of closely related formyl folates so that separation of pteroylmono- and diglutamates might reasonably be expected. It has not been possible to obtain a reference standard of pteroyldiglutamate, so that this point has not been specifically tested. The evidence, however, indicates clearly that the third peak is not formylated or methylated and that it is probably a monoglutamate.

On this basis it can be calculated that ordinary hospital diets provide an average of $20 \mu \mathrm{g}$ of PGA per day (range 4 to $69 \mu \mathrm{g}$ ). Our observations suggest that persons may consume diets of the type used in this study for prolonged periods without developing overt signs of PGA deficiency. Although some diets yielded as little as $4 \mu \mathrm{g}$ of PGA daily, it seems reasonable to assume that occasional consumption of liver or other foods would yield greater quantities of the vitamin and thereby prevent depletion of body stores.

Employing a bioautographic technique, Iwai and Nakagawa (26) were unable to demonstrate PGA in a variety of natural materials including green leaves, beef liver, and yeast. These authors concluded that most naturally occurring folates are in the formylated form. It is believed that the column chromatographic system employed in the present study has permitted detection of smaller amounts of PGA than would be possible with the filter-paper technique.

The evidence indicates that the second chromato- graphic peak is $\mathrm{CF}$ and that it constitutes $34 \%$ of the total folic acid-like activity present in these diets. In terms of its growth-supporting ability for $S$. fecalis, CF represents an average of $64 \mu \mathrm{g}$ daily and is present in greater amounts than PGA. Chang has reported the presence of $C F$ in a variety of animal livers as well as in kale and spinach (27). Bakerman (28) and Silverman, Keresztesy, Koval, and Gardiner (29) have shown that tetrahydropteroylglutamic acid has growth-supporting activity for $P$. cerevisiae if protected by ascorbate and if added aseptically to the culture medium. In the present study, the early autoclaving step tends to eliminate this factor, which is heat labile. The fact that the second peak behaves chromatographically like reference $\mathrm{CF}$ is a further indication that this component is indeed $\mathrm{CF}$ and not another factor that developed CF activity after elution from the column.

It is well-known that PGA is converted to CF in mammalian liver and that this conversion is blocked by certain folic acid antagonists (30). It is not known, however, if PGA alone will adequately replace other folic acid-active forms in human nutrition. Conversely, it is not known whether man can subsist entirely on methylated or formylated folates as the only dietary form of PGA. Woodruff, Peterson, and Darby have reported that a $75-\mu \mathrm{g}$ daily oral dose of $\mathrm{CF}$ is effective in treating the megaloblastic anemia of infancy (31). It has been reported that CF is effective in the treatment of tropical sprue (32-34), but there is disagreement as to its effectiveness in comparison with PGA. Since the latter studies were done with doses of CF that seem large by present day standards, and since the material administered could have contained microgram quantities of PGA, it will be necessary to make further observations on the comparative effectiveness of $\mathrm{CF}$ and PGA in human nutrition.

It should be mentioned that the chicken pancreas enzymes used in the present study may not be comparable to human intestinal or pancreatic enzymes. However, this has been a convenient and widely used source of conjugase. It has been reported that intestinal juice obtained from subjects with tropical sprue possesses conjugase activity (12), and such subjects are said to be capable of responding to conjugated forms of PGA (35). Chromatographic separation of folic 
acid factors, however, has not yet been carried out on foods after incubation with human intestinal or pancreatic enzymes.

On the basis of its action on synthetic and natural substrates, Kazenko and Laskowski (36) have presented evidence which indicates that the chicken pancreas conjugase should probably be classified as a $\gamma$-glutamic acid carboxypeptidase. It has been suggested that the end product of digestion with this enzyme is the pteroyldiglutamate, probably due to inhibition by the liberated glutamic acid (36). On the contrary, in the present study the enzyme from mixed diets yielded a product that corresponds to PGA in two chromatographic systems. Similarly, the use of conjugase derived from frésh hog kidney gave a chromatographic pattern which was identical to that obtained with the chicken pancreas preparation. The hog kidney conjugase reportedly converts pteroylpolyglutamates to the monoglutamate form (36). Although it is possible that both the mono- and the diglutamate forms would have similar elution characteristics, this seems unlikely. The findings suggest that PGA is liberated from the polyglutamate form of diets and that $20 \mu \mathrm{g}$ of PGA may be derived daily from average diets. The small quantities of active factors concerned in the present study have precluded chemical analysis of the number of glutamic acid residues. Work is in progress concerning the folic acid-active components of individual foods. Chromatographic analysis of liver and certain green vegetables has indicated two or more components as in the present study with mixed diets. This emphasizes the error inherent in methods that express growth-supporting activity of a food in terms of only one reference material; a vegetable, for example, may contain most of its activity in a form that is different from PGA. The present study emphasizes the variety of dietary compounds that have folic acid-like activity for microorganisms and points out the fallacy of assuming that this activity is equivalent to PGA.

\section{SUM MARY}

1) Folic acid assay by conventional methods with Streptococcus fecalis has shown that ordinary American diets contain $52 \pm 14 \mu \mathrm{g}$ of free folic acid activity per day. Assays performed after digestion of these same diets with chicken pan- creas conjugase yielded $184 \pm 67 \mu \mathrm{g}$ of total folic acid activity per day.

2) Fractionation of the digested material by column chromatography revealed three separate components with folic acid-like activity for $S$. fecalis. They represented 55,34 , and $11 \%$, respectively, of the total activity. Similar results were found with Lactobacillus casei.

3) Calculations indicate that these diets may yield under the conditions of this study a daily average of $101 \mu \mathrm{g}$ of $N^{10}$-formyl-pteroylglutamic acid, $63 \mu \mathrm{g}$ of citrovorum factor, and $20 \mu \mathrm{g}$ of pteroylglutamic acid.

4) It is suggested that certain compounds which possess folic acid-like activity in bacteriological assay systems may be inactive in human nutrition or at least inactive in the nutrition of patients with tropical sprue.

\section{ACKNOWLEDGMENT}

The authors wish to express their appreciation to $\mathrm{Mr}$. Leon P. Walker, Mr. Cecil Sutton, Mr. Oren Babb, Mr. Winston Edwards, and Mr. Frank Schabel for technical assistance.

We are indebted to Miss Carol Brewster for the preparation of the diets used in this study.

\section{ADDENDUM}

Additional evidence as to the daily total folic acid content of the American diet, with $S$. fecalis as the test organism, was reported by Chung and associates (37). Their average value for high cost diets was $193 \mu \mathrm{g}$ and for low cost diets, $157 \mu \mathrm{g}$. These values agree with the average value of $184 \mu \mathrm{g}$ reported in Table $\mathrm{I}$.

\section{REFERENCES}

1. Mitchell, H. K., and R. J. Williams. Folic acid. III. Chemical and physiological properties. J. Amer. chem. Soc. 1944, 66, 271.

2. Herbert, V., and R. Zalusky. Interrelations of vita$\min B_{12}$ and folic acid metabolism: folic acid clearance studies. J. clin. Invest. 1962, 41, 1263.

3. Crosby, W. H. The daily dose of folic acid. J. chron. Dis. 1960, 12, 583.

4. Flynn, L. M. Report on folic acid. J. Ass. official agricultural Chemists 1949, 32, 464.

5. Mims, V., and M. Laskowski. Studies on vitamin $B_{c}$ conjugase from chicken pancreas. J. biol. Chem. 1945, 160, 493.

6. Herbert, V. The assay and nature of folic acid activity in human serum. J. clin. Invest. 1961, 40, 81.

7. Baker, H., V. Herbert, O. Frank, I. Pasher, S. H. Hutner, L. R. Wasserman, and H. Sobotka. A 
microbiologic method for detecting folic acid deficiency in man. Clin. Chem. 1959, 5, 275.

8. Snell, E. E., and W. H. Peterson. Growth factors for bacteria. X. Additional factors required by certain lactic acid bacteria. J. Bact. 1940, 39, 273.

9. Silverman, M., L. W. Law, and B. Kaufman. The distribution of folic acid activities in lines of leukemic cells of the mouse. J. biol. Chem. 1961, 236, 2530.

10. Toennies, G., and P. M. Phillips. Blood folic acid studies. V. Resolution of precursor and enzyme fractions of the blood folic acid system. J. biol. Chem. 1959, 234, 2369.

11. Oliverio, V. T. Chromatographic separation and purification of folic acid analogs. Analyt. Chem. 1961, 33, 263.

12. Santini, R., Jr., F. M. Berger, G. Berdasco, T. W. Sheehy, J. Aviles, and I. Davila. Folic acid activity in Puerto Rican foods. J. Amer. diet. Ass. 1962, 41, 562.

13. Frieden, E. H., H. K. Mitchell, and R. J. Williams. Folic acid. II. Studies on absorption. J. Amer. chem. Soc. 1944, 66, 269.

14. Nichol, C. A., S. F. Zakrzewski, and A. D. Welch. Resistance to folic acid analogues in a strain of Streptococcus fecalis. Proc. Soc. exp. Biol. (N. Y.) 1953, 83, 272.

15. Usdin, E. Blood folic acid studies. VI. Chromatographic resolution of folic acid-active substances obtained from blood. J. biol. Chem. 1959, 234, 2373.

16. Council on Foods and Nutrition, American Medical Association. Vitamin preparations as dietary supplements and as therapeutic agents. J. Amer. med. Ass. 1959, 169, 41.

17. Sheehy, T. W., M. E. Rubini, E. Perez-Santiago, R. Santini, Jr., and J. Haddock. The effect of "minute" and "titrated" amounts of folic acid on the megaloblastic anemia of tropical sprue. Blood 1961, 18, 623.

18. Zalusky, R., and V. Herbert. Megaloblastic anemia in scurvy with response to 50 micrograms of folic acid daily. New Engl. J. Med. 1961, 265, 1033.

19. Herbert, V. Experimental nutritional folate deficiency in man. Trans. Ass. Amer. Phycns 1962, $75,307$.

20. Herbert, V. Minimal daily adult folate requirement. Arch. intern. Med. 1962, 110, 649.

21. Velez, H., J. Ghitis, A. Pradilla, and J. J. Vitale. Cali-Harvard nutrition project. I. Megaloblastic anemia in kwashiorkor. Amer. J. clin. Nutr. 1963, $12,54$.

22. Hansen, H. A., and A. Weinfeld. Metabolic effects and diagnostic value of small doses of folic acid and $B_{12}$ in megaloblastic anemias. Acta med. scand. 1962, 172, 427.
23. Girdwood, R. H. Folic acid, its analogs and antagonists. Advanc. clin. Chem. 1960, 3, 235.

24. Herbert, V. A palatable diet for producing experimental folate deficiency in man. Amer. J. clin. Nutr. 1963, 12, 17.

25. Noronha, J. M., and M. Silverman. Distribution of folic acid derivatives in natural material. I. Chicken liver folates. J. biol. Chem. 1962, 237, 3299.

26. Iwai, K., and S. Nakagawa. On the members of folic acid group in green leaves. Mem. res. Inst. food Sci. (Kyoto Univ.) 1958, 15, 40.

27. Chang, S. C. Availability of citrovorum factor in natural materials. J. biol. Chem. 1953, 200, 827.

28. Bakerman, H. A. A method for measuring the microbiological activity of tetrahydrofolic acid and other labile reduced folic acid derivatives. Analyt. Biochem. 1961, 2, 558.

29. Silverman, M., J. C. Keresztesy, G. J. Koval, and R. C. Gardiner. Citrovorum factor and the synthesis of formylglutamic acid. J. biol. Chem. 1957, 226, 83.

30. Charache, S., P. T. Condit, A. M. Levy, S. R Humphreys, and A. Goldin. Studies on the folic acid vitamins. V. The effect of folic acid on the citrovorum factor activity of mouse liver. Cancer (Philad.) 1960, 13, 241.

31. Woodruff, C. W., J. C. Peterson, and W. J. Darby Citrovorum factor and folic acid in the treatment of megaloblastic anemia in infancy. Proc. Soc. exp. Biol. (N. Y.) 1951, 77, 16.

32. Romero, C. A., R. Vizcarrondo, and R. RodriquezMolina. Treatment of sprue with folinic acid. Report of nine cases. Amer. J. med. Sci. 1952, 224, 9.

33. Suarez, R. M., E. C. Martinez, R. M. Suarez, Jr., and A. E. Latorre. The effect of citrovorum factor on the clinical picture and the clinical and neurological manifestations of tropical sprue. Bol. Asoc. méd. P. Rico 1951, 43, 319.

34. Spies, T. D., G. Garcia Lopez, F. Milanes, R. Lopez Toca, A Reboredo, and R. E. Stone. The response of patients with pernicious anemia, with nutritional macrocytic anemia and with tropical sprue to folinic acid or citrovorum factor. Sth. med. J. (Bgham, Ala.) 1950, 43, 1076.

35. Suárez, R. M., A. D. Welch, R. W. Heinle, R. M. Suárez, Jr., and E. M. Nelson. Effectiveness of conjugated forms of folic acid in the treatment of tropical sprue. J. Lab. clin. Med. 1946, 31, 1294.

36. Kazenko, A., and M. Laskowski. On the specificity of chicken pancreas conjugase $(\gamma$-glutamic acid carboxypeptidase). J. biol. Chem. 1948, 173, 217.

37. Chung, A. S., William N. Pearson, W. J. Darby, O. Neal Miller, and G. A. Goldsmith. Folic acid, vitamin $B_{6}$, pantothenic acid and vitamin $B_{12}$ in human dietaries. Amer. J. clin. Nutr. 1961, 9, 573. 